\title{
SCREENING CHECKLIST FOR AUDITORY PROCESSING IN ADULTS (SCAP-A): DEVELOPMENT AND PRELIMINARY FINDINGS
}

\author{
Ramya Vaidyanath, Asha Yathiraj \\ Department of Audiology, All India Institute of Speech and Hearing, Mysore, Karnataka, India
}

Corresponding author: Ramya Vaidyanath, Department of Audiology, All India Institute of Speech and Hearing, Mysore, Karnataka, India, e-mail: ramyavaidyanath@gmail.com

\begin{abstract}
Background: Auditory processing deficits can exist in older adults who have normal hearing sensitivity. However, checklists to screen for the condition are sparse. Hence, the study aimed to develop two screening checklists to identify auditory processing deficits in older adults, one for the individual and one for the family. The study also aimed to compare the responses on the two checklists.
\end{abstract}

Material/Methods: Through an interview, data were collected using the two developed checklists. The checklists, with 12 questions each, tapped auditory separation/closure, auditory integration, temporal ordering, as well as memory and attention. The checklists were administered on 102 participants aged 55 to 75 years and on 84 family members.

Results: It was found that $98 \%$ of the individuals had difficulty on at least one item of the checklist. Values on the kappa measure of agreement were higher when a 2-point rating scale was used instead of a 3-point one. Responses of older individuals formed five clusters, while those of the family members formed four. Responses to questions within each of the clusters varied; despite this variation, questions that were rated high or low were similar on the two checklists.

Conclusions: The study revealed that a large number of older individuals have symptoms of auditory processing disorders, and the checklists help to detect them. Validation of the checklists, which is in progress, would confirm their utility in detecting subjects with auditory processing difficulties.

Keywords: older individuals $\bullet$ screening checklist • auditory processing deficits $\bullet$ memory

\section{LISTADO DE CONTROL DE PRUEBAS DE CRIBADO DEL PROCESAMIENTO AUDITIVO EN ADULTOS (SCAP-A): DESARROLLO Y CONCLUSIONES PRELIMINARES}

\section{Resumen}

Introducción: Las deficiencias en el procesamiento auditivo pueden aparecer en personas de edad avanzada con la sensibilidad auditiva normal. Sin embargo, las listados de control para las pruebas de cribado de este estado, son pocos. Por este motivo, el objetivo de este estudio ha sido elaborar dos listados de control para identificar de las deficiencias del procesamiento auditivo en personas de edad avanzada- un listado individual y otro para las familias. El objetivo adicional de este estudio es la comparación de las respuestas de ambos listados.

Materiales y métodos: Los datos han sido obtenidos en una entrevista realizada en base a dos listados. Cada uno estaba compuesto de 12 preguntas relativas a la distinción/complementación de sonidos, integración auditiva, identificación de la estructura temporal de sonidos, como y también a la memoria y capacidad de atención. En la prueba han participado 102 personas de forma individual, en la edad de 55 a 75 años y 84 miembros de las familias.

Resultados: El 98\% de los participantes individuales ha tenido problemas al menos con un elemento del listado. Los valores del coeficiente kappa han sido más altos en la escala de dos en lugar de tres puntos de evaluación. Las respuestas de los participantes individuales pueden dividirse en cinco grupos, y las respuestas de los miembros de las familias- en cuatro. A pesar de las diferencias en las respuestas en cada uno de los grupos, las preguntas con mayor o menor valoración han sido similares en ambos listados de control.

Conclusiones: El estudio demuestra que los síntomas de trastornos del procesamiento auditivo son problema de un gran número de personas de edad avanzada. A la hora de su identificación han sido de ayuda los listados de control. El proceso de 
aprobación de listados de control está en curso. El resultado positivo de este proceso confirmaría su utilidad en la detección de trastornos del procesamiento auditivo.

Palabras clave: personas de edad avanzada • lista de comprobación de pruebas de cribado $\bullet$ deficiencias del procesamiento auditivo $\bullet$ memoria

\section{КОНТРОЛЬНЫЙ СПИСОК ПРОВЕРОЧНЫХ ИССЛЕДОВАНИЙ СЛУХОВОЙ ОБРАБОТКИ У ВЗРОСЛЫХ (SСАР-А): РАЗВИТИЕ И ПРЕДВАРИТЕЛЬНЫЕ ВЫВОДЫ}

\section{Изложение}

Введение: Дефицит слуховой обработки может появиться у старших людей с нормальной слуховой чувствительностью. Однако контрольные списки для проверочных исследований этого состояния - редкость. Поэтому цель ислледования - разработка двух контрольных списков для распознавания дефицита слуховой обработки у старших людей - одного индивидуального и одного для семей. Дополнительным преимуществом исследования является сравнение ответа с обоих списков.

Материал и методы: Данные были получены в опросе, проведенном на основании двух разработанных контрольных списков. Каждый состоял из 12 вопросов, касающихся различения/ дополнения звуков, слуховой интеграции, распознавания временной структуры звуков, а также памяти и сосредоточенности. В исследовании взяло участие 102 индивидуальных участника в возрасте 55-75 лет и 84 члена семей.

Результаты: 98\% индивидуальных участников имело проблему по крайней мере с одним элементом из списка. Значения каппа-коэффициента были выше в шкале двух вместо трех пунктов оценки. Ответы индивидуальных участников можно разделить на пять групп, тогда как ответы членов семей - на четыре. Несмотря на разницу в ответах на вопросы в каждой из групп, высоко или низко оцененные вопросы - подобные в обоих контрольных списках.

Заключение: Исследование показывает, что симптомы нарушений слуховой обработки касаются большого количества старших людей. В их обнаружении помогли контрольные списки. Идет процесс утверждения контрольных списков. Положительный результат этого процеса подтвердил бы их полезность в проверочных исследованиях расстройств слуховой обработки.

Ключевые слова: старшие люди • контрольный список проверочных исследований • дефицит слуховой обработки, память

\section{LISTA KONTROLNA BADAŃ PRZESIEWOWYCH PRZETWARZANIA SŁUCHOWEGO U DOROSŁYCH (SCAP-A): POSTĘP I WSTĘPNE WNIOSKI}

\section{Streszczenie}

Wstęp: Deficyty przetwarzania słuchowego mogą występować u osób starszych o normalnej wrażliwości słuchowej. Jednakże, listy kontrolne do badań przesiewowych tego stanu są rzadkością. Dlatego też, celem badania było opracowanie dwóch list kontrolnych do rozpoznawania deficytów przetwarzania słuchowego u osób starszych - jednej indywidualnej i jednej dla rodzin. Dodatkowym celem badania jest porównanie odpowiedzi z obu list.

Materiał i metody: Dane zostały uzyskane w wywiadzie przeprowadzonym na bazie opracowanych dwóch list kontrolnych. Każda składała się z 12 pytań dotyczących rozróżnienia/uzupełniania dźwięków, integracji słuchowej, rozpoznawania struktury czasowej dźwięków, jak również pamięci i koncentracji uwagi. W badaniu udział wzięło 102 uczestników indywidualnych w wieku 55-75 lat oraz 84 członków rodzin.

Rezultaty: 98\% uczestników indywidualnych miało problem przynajmniej z jednym elementem z listy. Wartości współczynnika kappa były wyższe w skali dwóch zamiast trzech punktów oceny. Odpowiedzi uczestników indywidualnych można podzielić na pięć grup, natomiast odpowiedzi członków rodzin - na cztery. Pomimo różnic w odpowiedziach na pytania w każdej z grup, pytania ocenione wysoko lub nisko były podobne na obu listach kontrolnych. 
Wnioski: Badanie pokazuje, że symptomy zburzeń przetwarzania słuchowego dotyczą dużej liczby osób starszych. W ich wykryciu pomogły listy kontrolne. Proces zatwierdzania list kontrolnych jest w toku. Pozytywny wynik tego procesu potwierdziłby ich użyteczność w badaniach przesiewowych zaburzeń przetwarzania słuchowego.

Słowa kluczowe: osoby starsze • lista kontrolna badań przesiewowych • deficyty przetwarzania słuchowego • pamięć

\section{Background}

With aging, changes in the central auditory system have been reported by many researchers [1-3]. These changes have been noted to result in auditory perceptual difficulties $[4,5]$. The perceptual problems that have been reported in these individuals include difficulties in speech discrimination abilities [6] and deficits in the processing of auditory signals [7]. Researchers have also indicated that central auditory processing deficits occurred in the absence of a significant cognitive decline and peripheral hearing impairment $[6,8]$.

In the literature, screening for auditory processing has been mainly documented in children [9-16]. Musiek et al. [17] reported that without the use of screening procedures, the difficulties experienced would either not be identified or be identified late.

The American Speech and Hearing Association [ASHA; 18 ] advocates that screening for auditory processing disorders (APD) could involve observation of listening behavior and/or performance on tests. To obtain information on auditory behavior, the use of "questionnaires, checklists, and other related measures" was recommended (ASHA, 2005 , p. 5). Although they report several screening protocols, the focus of these have been on identifying children at risk for auditory processing disorders.

The American Academy of Audiology [AAA; 19] and the Canadian Interorganizational Steering Group for Speech - Language Pathology and Audiology [20] suggested the use of checklists or inventories answered by the individuals themselves or others associated with them (parents, employers, spouses, or significant others) to detect auditory processing problems. These were reported to provide information on the auditory difficulties experienced by the individual and their impact on day-to-day activities.

Several screening tools are available to detect APD in children [9-16,21,22]. However, screening procedures for adults are relatively few. Some of the screening procedures used for adults are a 'Test for auditory processing disorders in adolescents and adults' [SCAN-A; 23] and SCAN-3 for adolescents and adults [24]. ASHA [18] and AAA [19] note that the tools listed by them lacked specificity and usually led to over-referrals. The two guidelines set out a need for a valid and efficient tool for screening auditory processing deficits. Thus, there is a need for screening tools to identify APD in adults.

Schow and Seikel [25] noted that observable signs of the presence of APD can be detected through questionnaires answered by caregivers or teachers. However, they cautioned that the responses could be contaminated by the subjective bias of the respondent.
Despite the subjective nature of questionnaires or checklists used for screening, their utility cannot be undermined, especially in countries with large populations. The number of older adults is reported to be steadily increasing in many countries, including India. According to Kinsella and $\mathrm{He}$ [26], the population above the age of 65 years in the world is expected to double from $7 \%$ to about $14 \%$, increasing from 506 million in the year 2008 to 1.4 billion by the year 2040 . They reported that in countries like India and China the aging population is expected to increase from 166 million in 2008 to 550 million in 2040. In India, as per the Central Statistics Office, Ministry of Statistics and Programme Implementation [27], the population above the age of 60 years is expected to almost double in about two decades: it is predicted to increase from $7.4 \%$ in 2001 to $12.4 \%$ of the Indian population by the year 2026 .

With an increase in the number of older individuals, it is also expected that the number of individuals with auditory processing deficits would increase proportionally. Early identification of these individuals will help in making appropriate referrals, which in turn might help in early diagnosis and management of the problem. As tools to identify APD in older individuals are sparse, there is a need to develop them. Hence, the current study aimed to develop two checklists to detect the presence of APD in older individuals, one to be answered by the individuals themselves and another to be answered by close family members. The study also aimed to compare the responses on the two checklists.

\section{Material and Methods}

The study involved development of two checklists. This entailed the compilation of the content of the checklists as well as their validation by professionals working in the area of APD. The checklists were administered on older individuals and their family members.

\section{Development of the checklists}

The 'Screening checklists for auditory processing for adults' (SCAP-A) were adapted from the 'Screening checklist for auditory processing' (SCAP) developed by Yathiraj and Mascarenhas $[15,16]$. The latter was developed to screen children for auditory processing. SCAP has 12 questions that tap different aspects of auditory processing such as auditory separation/closure, auditory memory, and auditory attention. It is scored on a 2-point rating scale and children who obtain more than the $50 \%$ score (a score $\geq 6$ ) are considered at risk for auditory processing deficits. The checklist was designed to be administered by a class teacher.

SCAP-A was developed along the lines of SCAP to have 12 questions that tap auditory separation/closure, memory, and attention. Only five questions that were relevant for adults were selected from SCAP for SCAP-A. The 
remaining seven questions were selected from aspects that were reported in the literature to commonly affect older adults [28-31]. Two checklists, one to be answered by the individual themself and the other to be answered by a family member were developed. They were constructed such that they tapped similar areas, but were worded differently. Item validity was done by having the checklists assessed by seven audiologists who have worked in the area of auditory processing for at least 3 years. They were asked to indicate the auditory process that was assessed by each of the questions. Additionally, they were asked to indicate whether any of the questions was ambiguous, and these were reframed. Based on the responses of the audiologists, the questions targeted auditory integration, auditory separation/closure, temporal ordering, memory, and attention (Appendix 1 and 2).

The checklists were initially developed in English and were translated into Kannada, the language spoken in southern India, by a native speaker. The translated checklists were given to 6 other native speakers to ensure that the questions were understandable to individuals with a minimum 8th grade education. Reverse translation of the finalised checklists from Kannada into English was done by two individuals with knowledge of both English and Kannada. The reverse-translated checklists and the original English version were compared for meaning, and changes were made to the Kannada translations if the original English version and the reverse-translated version were not similar. A 3-point rating scale ('always', 'sometimes', and 'almost never') was used to obtain responses for both checklists. 'Always' indicated that the situation was experienced more than $75 \%$ of the time; 'sometimes' indicated that the situation was faced 50 to $75 \%$ of the time, and 'almost never' indicated that the situation was experienced less than $50 \%$ of the time. Details of the scoring of the two checklists are given in Appendix 1 and 2.

\section{Study sample}

The checklist to be answered by older individuals (Appendix 1) was administered on 102 participants (50 males and 52 females) in the age range of 55 to 75 years (mean 63.2 years). The above age group was chosen since individuals are considered as senior citizens at 60 years of age, according to 'The Maintenance and Welfare of Parents and Senior Citizens Act' [2007], Government of India. Further, since auditory processing deficits could exist prior to a person being considered a senior citizen, individuals from the age of 55 years were also included. Among them, 70 were in the age range of 55 to 65 years and 32 in the age range of 65 to 75 years. The participants included in the study were recruited only if they did not report any otological problem, presence of hearing loss, or any neurological deficits. This was confirmed based on their history and medical reports. Further, the participants selected were required to have passed at least $8^{\text {th }}$ grade and have been educated in either English or Kannada. Additionally, the checklist to be answered by the family members (Appendix 2) was administered on 84 of the family members who were familiar with and had interacted regularly with the older individual for at least 5 years prior to the evaluation. However, the majority of family members had known the older individuals for an average of 20 years. Only one family member, usually the spouse, of a particular participant was administered the checklist. Other family members were recruited only if the spouse was unavailable. For 18 participants, family members were not available to administer the checklist.

\section{Procedure}

The checklists were administered on the participants and their family members, individually, in a quiet room free from disturbances. The procedure used was as per the requirements stipulated by the ethical guidelines of the All India Institute of Speech and Hearing, Mysore [32]. The same examiner administered the checklists on all participants. The questions in the checklist were read out to the individuals and they rated the difficulties or abilities on the 3 -point rating scale. Their responses were noted by the examiner and scored later. The scores obtained on individual questions as well as the cumulative score were tabulated.

\section{Statistical analysis}

Descriptive statistics, which included mean, standard deviation (SD), and independent sample $t$-test, were used to compare the total scores obtained by the two age groups. A kappa measure of agreement was obtained to evaluate agreement between the responses obtained from the two checklists. Additionally, cluster analysis was done to determine the questions that could be grouped together.

\section{Results}

The differences in responses of the two age groups (55 to 65 years and 65 to 75 years) were compared to observe the effects of age on the processes being tapped. This effect of age was done separately for the checklist answered by the individuals themselves and the one answered by the family members. The degree of agreement of the responses on the two checklists answered by the older individuals and their family members were determined. Further, to establish if the questions within each of the checklists could be grouped, a cluster analysis was carried out.

The mean and standard deviation of the responses of the two groups of older individuals (55 to 65 years and 65 to 75 years) varied marginally, as can be seen in Table 1 . The mean total score of the older of age group ( 65 to 75 years) was higher than that of the younger age group (55 to 65 years). However, an independent sample $t$-test revealed that the difference in the overall scores between the two age groups was not statically significant $[t=0.898, \mathrm{df}=100$, $p>$.05]. Additionally, an independent sample $t$-test of the responses obtained from the family members of the two age groups showed no significant difference between the scores of the two age groups $[t=0.115, \mathrm{df}=82, p>.05]$. As no significant difference was obtained between the two groups, their scores were combined for further statistical analyses.

To evaluate the agreement between the responses of the two checklists answered by the older individuals and their family member, Cohen's kappa was calculated. The kappa measure of agreement between the scores on the two checklists (answered by the older individuals and by 
Table 1. Mean score of the two age groups

\begin{tabular}{cccc}
\hline Age group & No. of participants & Mean* & SD \\
\hline 55 to 65 years & 70 & 5.43 & 3.47 \\
\hline 65 to 75 years & 32 & 6.09 & 3.48 \\
\hline * Maximum possible score $=24$ & &
\end{tabular}

Table 2. Comparison of the kappa measure of agreement obtained using 3- and 2-point rating scales between each of the questions of the checklists answered by the older individuals and their family members

\begin{tabular}{ccccc}
\hline \multirow{2}{*}{$\begin{array}{c}\text { Question } \\
\text { number }\end{array}$} & \multicolumn{4}{c}{ Kappa } \\
\cline { 2 - 5 } & \multicolumn{2}{c}{ 3-point rating } & 2-point rating \\
\hline Question 1 & \multicolumn{3}{c}{0.13} & $(0.182)$ \\
\hline Question 2 & -0.06 & $(0.529)$ & -0.114 & $(0.296)$ \\
\hline Question 3 & 0.14 & $(0.093)$ & 0.259 & $(0.012)^{\star}$ \\
\hline Question 4 & 0.15 & $(0.096)$ & 0.193 & $(0.074)$ \\
\hline Question 5 & 0.12 & $(0.211)$ & 0.243 & $(0.025)^{\star}$ \\
\hline Question 6 & 0.09 & $(0.294)$ & 0.071 & $(0.512)$ \\
\hline Question 7 & 0.18 & $(0.023)^{*}$ & 0.263 & $(0.015)^{\star}$ \\
\hline Question 8 & 0.13 & $(0.093)$ & 0.237 & $(0.014)^{\star}$ \\
\hline Question 9 & 0.1 & $(0.201)$ & 0.142 & $(0.146)$ \\
\hline Question 10 & 0.04 & $(0.645)$ & 0.071 & $(0.515)$ \\
\hline Question 11 & 0.31 & $(0.0)^{\star * *}$ & 0.355 & $(0.001)^{\star * *}$ \\
\hline Question 12 & -0.02 & $(0.835)$ & 0.029 & $(0.775)$ \\
\hline
\end{tabular}

${ }^{\star} p<.05 ;{ }^{* *} p<.01 ;{ }^{* *} p<.001$

family members) was obtained for all but the first question (Table 2). The agreement could not be calculated for question 1 as it was rated 0 or 1 and never 2, thereby not meeting the requirement of kappa to have all points on the rating scale represented.

The kappa measure of agreement between the responses of the two participant groups was low (Table 2) and was significant only for two questions when the checklists were scored using the 3-point rating. Additionally, from the raw scores it was observed that the rating of ' 2 ' was infrequent (older individuals $=111$ out of 1224 ; family $=79$ out of 1008) compared to a rating of ' 1 ' (older individuals $=353$ out of 1224 ; family $=286$ out of 1008 ). Hence, the agreement and level of significance was calculated by converting the responses to a 2-point rating scale. All the responses that indicated the presence of a problem (ratings of ' 1 ' and ' 2 ') were merged and rated as ' 1 ', and the absence of the problem was rated as ' 0 '. The maximum obtainable score with the 2-point rating was 12 . The agreement between the two participant groups was higher with the use of the 2-point rating scale compared to the 3-point rating scale. Further, the number of questions that had a significant agreement increased from 2 to 5 with the use
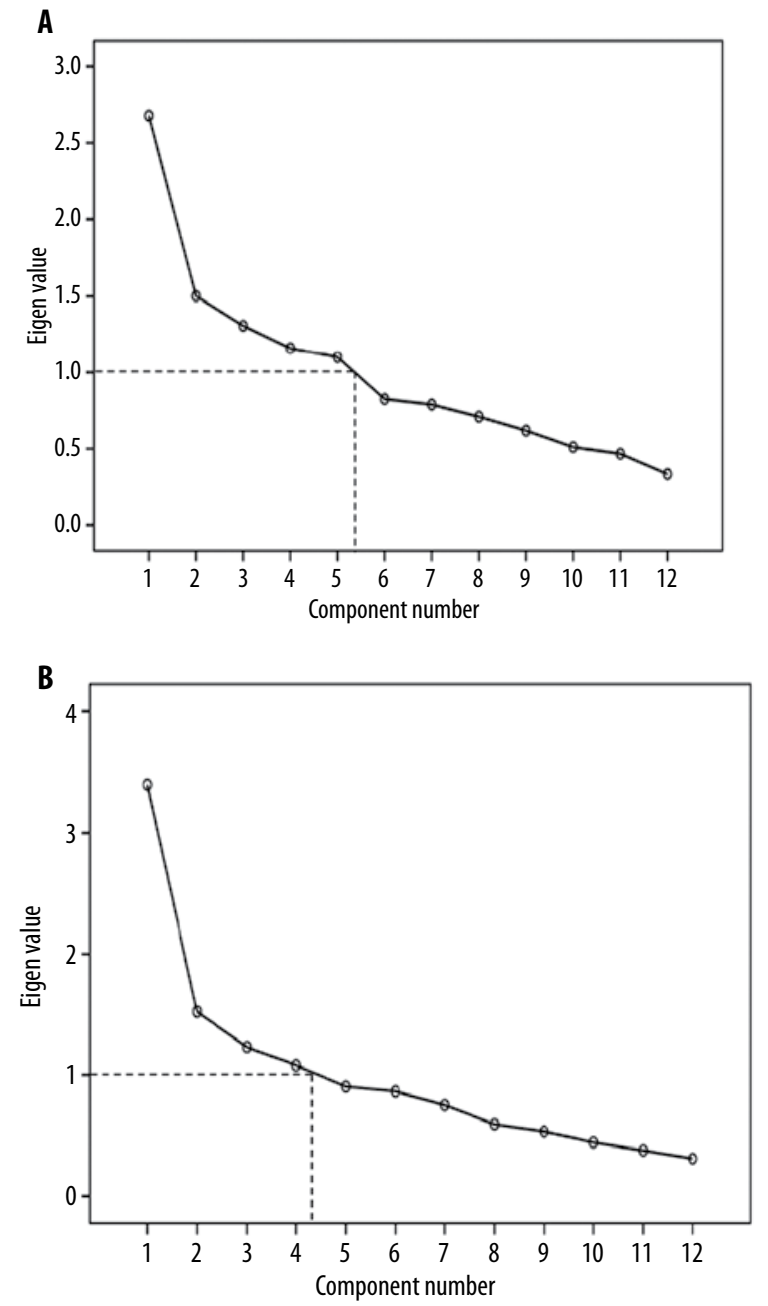

Figure 1. Scree plots obtained from the responses of the older individuals (A) and from their family members (B)

of the 2-point rating scale (Table 2). Although the agreement was low, it was significant for questions $3,5,7,8$, and 11 . Hence, the subsequent analyses were carried out using the 2-point rating scale.

To evaluate the internal consistency of the items in the two checklists, Cronbach's alpha was measured. The alpha value for the checklists answered by the older individuals was 0.64 and that answered by the family members was 0.75 . The relatively low Cronbach's value could be due to the number of items being less in each of the questions, as noted by Tavakol and Dennik [33].

Based on scree plots obtained for the responses of the older individuals (Figure 1A) and their family members (Figure 1B), clusters having an eigenvalue greater than 1 were selected. Five clusters were formed from the responses of the older individuals when the 2-point rating scale was used (Figure 2). The first cluster mainly consisted of four questions relating to memory and attention. The second and the fifth clusters had only one question each pertaining to attention and auditory perception in the absence of visual cues. The third cluster had three questions solely 


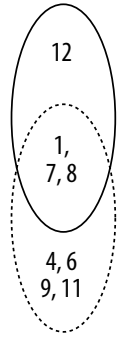

Cluster 1

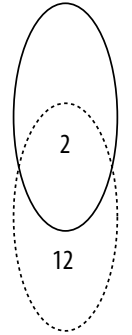

Cluster 2

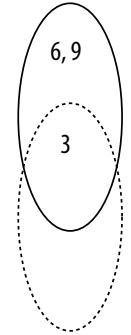

Cluster 3

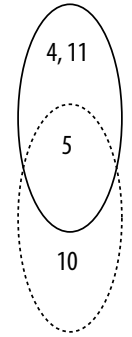

Cluster 4

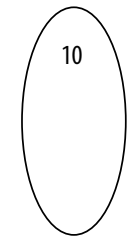

Cluster 5
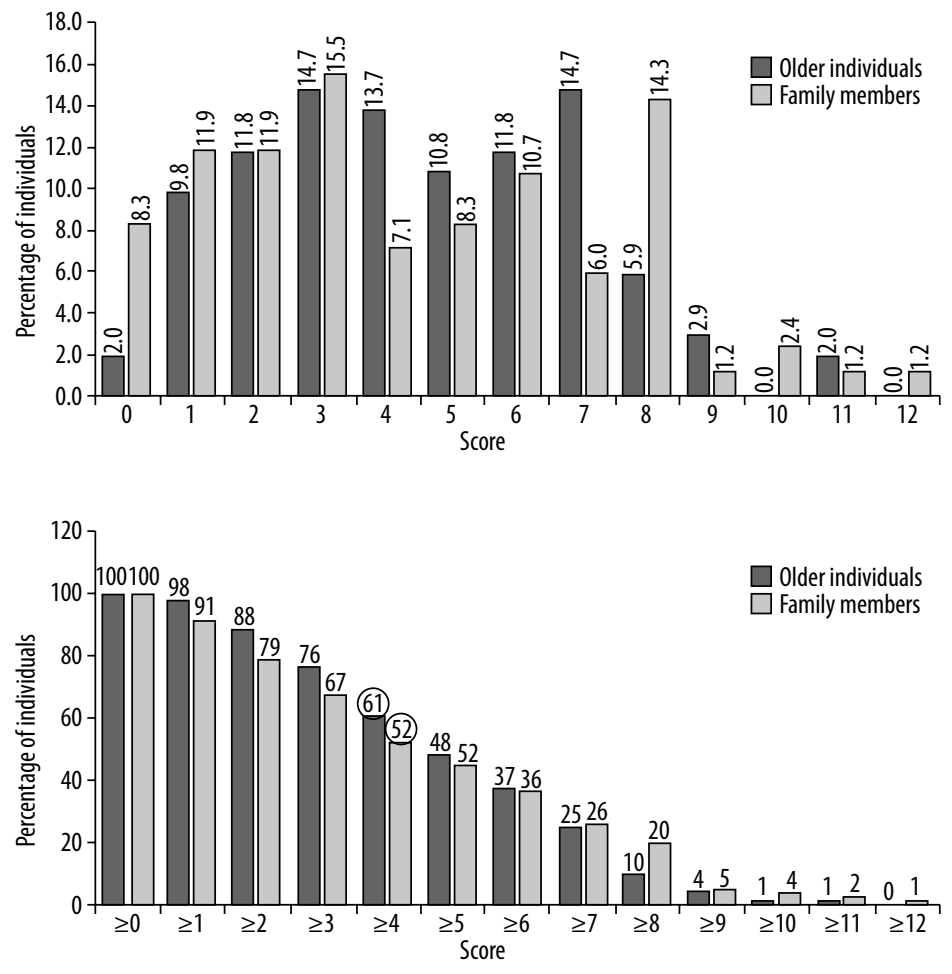

Figure 2. Clusters formed from the responses of the older individuals (solid line) and their family members (dashed lines) on the two checklists. The intersections show the questions that were common within sets of clusters. Questions 1, 5, 7, and 11 tapped 'memory'; questions 2, 8, and 12 tapped 'attention'; questions 3, 6, and 9 tapped 'auditory separation/closure'; question 4 tapped 'temporal ordering'; question 10 tapped 'auditory perception without accompanying cues'

Figure 3. Distribution of the scores on the two checklists

Figure 4. Comparison of the distribution of the scores relating to auditory separation/closure, and the fourth cluster had three questions assessing memory and temporal ordering.

Unlike the findings of the cluster analysis of the responses of the older individuals, the responses on the checklist answered by the family members formed four clusters. Thus, clusters formed from the two checklists were not similar (Figure 2).

Additionally, the distribution of the scores on the two checklists (Figure 3 ) indicates the difference in auditory processing difficulties perceived by the older individuals and by their family members. The percentage of older individuals who reported no auditory difficulties (2.0\%) was less than the percentage reported by the family members $(8.3 \%)$. However, from Figure 4 it can be observed that considering all questions the median score was the same for both checklists (median =4). Out of 102 older individuals it was observed that $61 \%(n=63)$ obtained a total score greater than or equal to 4 . On the other hand, $52 \%(n=44)$ of the family members gave scores greater than or equal to 4 (Figure 4 ).

The number of older individuals with a positive symptom on each question in the checklist was also determined (Figure 5). More than $50 \%$ of the older individuals reported difficulties on four of the questions that tapped information regarding auditory separation/closure (questions 9, 3, and 6) as well as memory for sequences of numbers (question 11). The family members also rated the older individuals as having more problems in the same four questions (questions 6, 9, 11, and 3).

Thus, from the results of the study it is evident there was no difference in the two age groups that were evaluated. The majority of the 102 older individuals reported at least one symptom of an auditory processing deficit. The older 


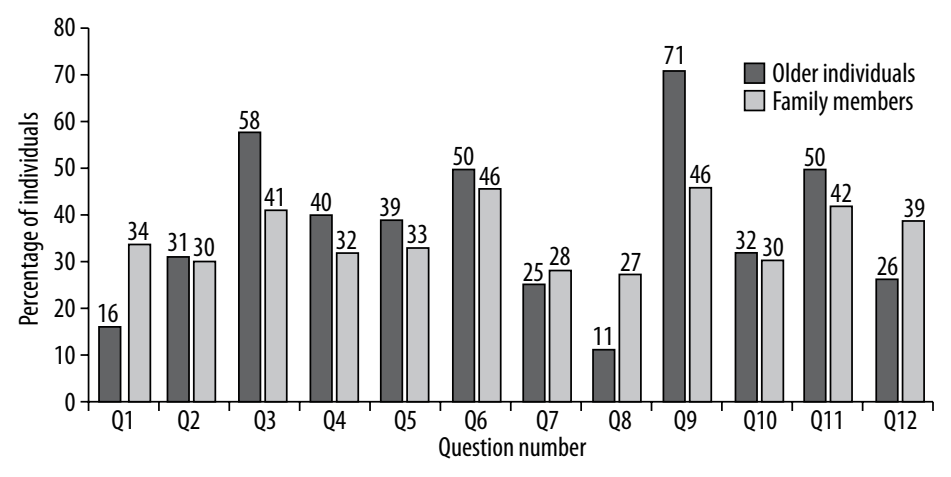

Figure 5. Number of individuals with positive symptoms for each of the questions individuals and their families reported that the problem was greater for auditory separation/closure and memory for sequences of numbers. Although the older individuals and their family members reported that the problem was greater on similar aspects, the order of the difficulty varied.

\section{Discussion}

The findings of the current study provide insight into how the symptoms of auditory processing deficits are perceived in older individuals aged 55 to 65 and 65 to 75 years. Additionally, a comparison of the perception of auditory processing difficulties in older individuals themselves and by their family members was also obtained.

The lack of a significant difference between the responses of the two older age groups on the SCAP-A indicate that the symptoms tapped did not vary much with age. Only a marginal increase in the presence of auditory processing symptoms occurred with advance in age. Unlike what has been reported in the literature $[34,35]$, the older age group in the present study (65 to 75 years) did not report greater difficulties compared to the younger group (55 to 65 years). The absence of a significant difference between the two age groups in the current study may have occurred because the checklists were not sensitive enough to detect the subtle perceptual changes that take place with aging.

The agreement between the two checklists was better using a 2 -point rating scale than a 3 -point rating scale. This reflects a lack of consensus between the older individuals and their family when a larger rating scale was used. Rating only the presence or absence of symptoms resulted in a greater consensus, probably due to easier decision-making.

In the current study, the developed checklist was designed to assess four processes: auditory separation/closure, memory, attention, and temporal ordering. However, cluster analysis of the responses on the checklist answered by the older individuals revealed that the questions could be grouped into five clusters. This occurred since certain processes were represented in more than one cluster. Questions related to memory were represented in two clusters (clusters 1 and 4 ) as was attention (clusters 1 and 2). This indicates that the checklists elicited information regarding different aspects of memory and attention.

The grouping of questions related to memory and attention into the first cluster indicates a relation between the two. This finding is in accordance with that of Larrabee and Levin [36] who reported a relation between self-reports of decline in memory and objective measures of attention/concentration. Park et al. [37] also noted that for older individuals, memory for words was more affected when attention was divided at the encoding stage rather than during the process of retrieval. Similarly, Anderson et al. [38] reported reduced activity in the prefrontal regions of the brain using PET. This was noted in the older adults during the stages of encoding and retrieval during full and divided attention tasks. They also reported that divided attention during the process of encoding reduced performance in memory. The findings of the current study substantiate the link between attention and memory.

The cluster analysis of the responses of the family members (Figure 2) revealed that the contents of the clusters were different from that of the responses of the older individuals. This indicates a difference in perception of auditory processing symptoms by the older individuals and by their family members.

The grouping of questions tapping attention, memory, and auditory separation/closure in the checklist answered by the family members shows a relation between these aspects. This clustering substantiates the tolerance-fading memory category of auditory processing disorders described by Katz [39]. This subgroup of auditory processing disorders was reported to have difficulty in speech perception in the presence of noise along with rapidly fading memory. This was attributed to damage to the anterior temporal region that has been reported by Efron et al. [40] to be associated with difficulties in auditory figure - ground separation. The anterior temporal region contain the hippocampus and amygdala that are associated with memory [41,42]. Additionally, damage to the frontal lobes was observed to result in difficulties in perception of two stimuli presented together [43]. An association between reduced activity or volume of the hippocampal regions of the brain and verbal memory performance in older nondemented individuals has also been observed [44-46].

The link between attention, memory, and auditory separation/closure, found in the current study, adds to the corpus of findings indicating a close association between them. Although this association was seen from the responses obtained from the family members, it was not present from the responses of the older individuals. This probably occurred since the older individuals did not perceive themselves as having a memory problem while listening in the presence of noise, but the problem was observed by family members. 
The results of the present study indicate that the majority of older individuals experience at least one symptom of difficulty in auditory processing related to memory (Figure 5). The older individuals as well as their family members reported the presence of multiple symptoms of auditory processing (Figure 4). A larger number of family members reported no symptoms of auditory processing problems in the older individuals compared to the older individuals themselves (Figure 3). From this, it can be interpreted that the subtle difficulties experienced by the older individual are not readily noticed by family members.

Further, the results also indicate that the scores on the two checklists rarely exceeded $50 \%$ ( $>6$ out of a maximum possible score of 12), as can be seen in Figure 4. From this, it can be construed that the older individuals did not experience problems in all areas evaluated in the checklist and the family members also made a similar observation. The problems were reported to be more prominent in conditions requiring auditory separation/closure (questions 3, 6 , and 9) and sequences of numbers (question 11). However, the symptoms that were reported to be less evident were related to auditory attention (question 8), as can be seen in Figure 5. A possible reason why attention was not reported to be a problem by both groups of participants could be because other symptoms are more disconcerting.

The more prominent problems reported in conditions requiring auditory separation/closure and memory finds support in the findings of Wong et al. [47]. Using fMRI they found a significant relation in older individuals between behavioral performance in the presence of noise and the area of activation around the prefrontal cortex and the precuneus, areas responsible for working memory and attention. Wong et al. reported considerable decline in activity in the superior temporal gyrus when stimuli were presented at $-5 \mathrm{~dB}$ SNR, but an increase in the attention and working-memory related areas. In the current study, perception in the presence of noise and memory was perceived as being a problem in more individuals compared to attention. This could be due to older individuals not being aware of their difficulties in attending to auditory stimuli. In contrast, they were aware of their difficulties in perception of speech in the presence of noise as well as their memory problems. This possibly occurred because attention is a more passive task that may not be noticeable to older individuals or their family members. On the other hand, auditory separation/closure and memory are more active tasks involving interaction between the participant groups, making them more noticeable.
In the present study, one of the questions that many reported difficulty with was a problem in listening to two people speaking simultaneously (question 9). This concurs with the findings of Murphy et al. [48] who reported that older listeners have difficulty following a two-person conversation. They ascribed this difficulty to problems in spatial separation rather than an increase in cognitive requirements. Thus, it can be construed that listening to two people talking simultaneously probably taps auditory integration, while listening in the presence of noise would mainly involve auditory separation. Thus, it is essential to include both questions in a checklist designed to detect auditory processing problems in older individuals. It is necessary that the findings of the current study be validated by administrating diagnostic auditory processing tests. This would confirm the utility of the two checklists. Validation of the two checklists is underway as part of this ongoing study.

\section{Conclusions}

The findings of the current study indicate that a large number of older individuals experience at least one symptom relating to deficits in auditory processing or memory. However, the extent of these symptoms varies from individual to individual. The poor agreement between the two checklists answered by the older individuals and their family members indicates a lack of consensus. The two checklists reveal that auditory separation/closure and memory are aspects where a large percentage of older individuals experience difficulties.

Although the agreement between the two checklists was found to be poor, auditory separation/closure and memory were rated as being difficult by a large percentage of individuals in both groups. Hence, when administered together these checklists provide complementary information. This would help in the counseling of the older individuals and their family members regarding the presence of symptoms of auditory processing deficits. Additionally, it would also help in making recommendations for referrals. As part of the current ongoing study, validation of the two checklists is under way.

\section{Acknowledgments}

The researchers thank the All India Institute of Speech and Hearing, Mysore, for facilities to carry out the present research. We also thank all the participants.

Appendix 1. Screening Checklist for Auditory Processing in Adults (SCAP-A) - Modified 2-point rating scale ${ }^{a}$ (Report by Self)

Name:

Date:

Age:

Gender: Male/Female

Please tick $(\sqrt{ })$ the most appropriate option

\begin{tabular}{clcc}
\hline \multirow{2}{*}{ No. } & Questions & \multicolumn{2}{c}{ Score } \\
\cline { 3 - 4 } & & Present & Absent \\
\hline 1 & $\begin{array}{l}\text { Do you require frequent repetitions while listening to someone who does not } \\
\text { have a speech problem? }\end{array}$ & 1 & 0 \\
\hline
\end{tabular}




\begin{tabular}{|c|c|c|c|}
\hline 2 & $\begin{array}{l}\text { Can you pay attention to someone speaking continuously for more than } 10 \text { minutes? } \\
\text { E.g. Listening to a conversation. }\end{array}$ & 0 & 1 \\
\hline 3 & $\begin{array}{l}\text { Do you find it difficult to attend to speech in the presence of background noise? } \\
\text { E.g. Television at normal volume/fan at high speed. }\end{array}$ & 1 & 0 \\
\hline 4 & $\begin{array}{l}\text { Do you have trouble recalling what was said in the correct order? } \\
\text { E.g. } 5 \text { different (non-routine) things in the order you have done them }\end{array}$ & 1 & 0 \\
\hline 5 & $\begin{array}{l}\text { Do you forget what was told to you within a short span of time (within a minute)? } \\
\text { E.g. To buy a particular item from a shop }\end{array}$ & 1 & 0 \\
\hline 6 & $\begin{array}{l}\text { Do you have difficulty in understanding speech in the presence of background } \\
\text { noise (when the television/fan at full speed)? }\end{array}$ & 1 & 0 \\
\hline 7 & $\begin{array}{l}\text { Can you recall the names of } 5 \text { of your school/ college friends, who you have not } \\
\text { met after you left school/college? }\end{array}$ & 0 & 1 \\
\hline 8 & $\begin{array}{l}\text { Have you been told that you take longer than others to respond when your } \\
\text { friends or family talk to you? }\end{array}$ & 1 & 0 \\
\hline 9 & $\begin{array}{l}\text { Do you have difficulty in responding to two people talking at the same time? } \\
\text { E.g. In a group, when two people answer/ask a question at the same time. }\end{array}$ & 1 & 0 \\
\hline 10 & $\begin{array}{l}\text { Do you feel it is difficult to understand someone's speech when you cannot see } \\
\text { his or her face? } \\
\text { E.g. When the person's face is turned away from you. }\end{array}$ & 1 & 0 \\
\hline 11 & $\begin{array}{l}\text { Do you have difficulty in remembering numbers, especially telephone/vehicle/ } \\
\text { door numbers, bus numbers, account numbers? }\end{array}$ & 1 & 0 \\
\hline 12 & $\begin{array}{l}\text { Do others report that you do not attend to them when they suddenly start } \\
\text { talking to you? }\end{array}$ & 1 & 0 \\
\hline
\end{tabular}

Thank you for the careful completion of this questionnaire

a The scoring for the checklist was modified into a 2-point rating based on the results obtained.

Appendix 2. Screening Checklist for Auditory Processing in Adults (SCAP-A) - Modified 2-point rating scale ${ }^{a}$ (Report by Family)

Name:

Date:

Age:

Family member of:

Relationship:

\begin{tabular}{|c|c|c|c|}
\hline \multirow{2}{*}{ No. } & \multirow{2}{*}{ Questions } & \multicolumn{2}{|c|}{ Score } \\
\hline & & Present & Absent \\
\hline 1 & $\begin{array}{l}\text { Does she/he require frequent repetitions while listening to you or someone who } \\
\text { speaks clearly? }\end{array}$ & 1 & 0 \\
\hline 2 & Can she/he attend to someone speaking continuously for more than 10 minutes? & 0 & 1 \\
\hline 3 & $\begin{array}{l}\text { Does she/he find it difficult to attend to speech in the presence of background } \\
\text { noise? }\end{array}$ & 1 & 0 \\
\hline 4 & $\begin{array}{l}\text { Does she/he have trouble recalling what was said in the correct order? } \\
\text { E.g. } 5 \text { different (non-routine) things in the correct order }\end{array}$ & 1 & 0 \\
\hline 5 & $\begin{array}{l}\text { Does she/he forget what was told very quickly within a short span of time } \\
\text { (within a minute)? } \\
\text { E.g. To buy a particular item from a shop }\end{array}$ & 1 & 0 \\
\hline 6 & $\begin{array}{l}\text { Does she/he have difficulty in understanding in the presence of background } \\
\text { noise (when the television/fan at full speed)? }\end{array}$ & 1 & 0 \\
\hline 7 & $\begin{array}{l}\text { Can she/he recollect the names of } 5 \text { friends whom they have not met over } 30 \\
\text { years? }\end{array}$ & 0 & 1 \\
\hline 8 & $\begin{array}{l}\text { Does she/he take much longer (almost double the time) to respond to what was } \\
\text { said compared to others in the family/friends? }\end{array}$ & 1 & 0 \\
\hline 9 & $\begin{array}{l}\text { Does she/he have difficulty in responding to two people talking almost at the } \\
\text { same time? }\end{array}$ & 1 & 0 \\
\hline 10 & $\begin{array}{l}\text { Does she/he have difficulty in understanding speech when the face of the } \\
\text { speaker cannot be seen? }\end{array}$ & 1 & 0 \\
\hline 11 & $\begin{array}{l}\text { Does she/he have difficulty in recalling digits, especially telephone/vehicle/door } \\
\text { numbers, bus numbers, account numbers? }\end{array}$ & 1 & 0 \\
\hline 12 & $\begin{array}{l}\text { Does she/he not attend to you or others when you or others suddenly start } \\
\text { talking to her/him? }\end{array}$ & 1 & 0 \\
\hline
\end{tabular}

Thank you for the careful completion of this questionnaire

a The scoring for the checklist was modified into a 2-point rating based on the results obtained 


\section{References:}

1. Willott J, Lister J. The aging auditory system: anatomic and physiologic changes and implications for rehabilitation. Int J Audiol, 2003; 42: 2S3-2S10.

2. Frisina RD. Possible neurochemical and neuroanatomical bases of age-related hearing loss - presbycusis. Semin Hear, 2001; 22(3): 213-26.

3. Stach BA, Hornsby BW, Rosenfeld MAL, DeChicchis AR. The complexity of auditory aging. Semin Hear, 2009; 30(2): 94-111.

4. Jerger J. Audiological findings in aging. Adv Otorhinolaryngol, 1973; 20: 115-24.

5. Konkle DF, Beasley DS, Bess FH. Intelligibility of time-altered speech in relation to chronological aging. J Speech Hear Res, 1977; 20(1): 108.

6. Rodriguez GP, DiSarno NJ, Hardiman CJ. Central auditory processing in normal-hearing elderly adults. Int J Audiol, 1990; 29(2): 85-92.

7. Jerger J, Chmiel R, Allen J, Wilson A. Effects of age and gender on dichotic sentence identification. Ear Hear, 1994; 15(4): 274-86.

8. Jerger J, Jerger S, Oliver T, Pirozzolo F. Speech understanding in the elderly. Ear Hear, 1989; 10(2): 79-89.

9. Anderson K. SIFTER: Screening Instrument for Targeting Educational Risk in Children Identified by Hearing Screening or Who Have Known Hearing Loss. Tampa, FL: Educational Audiology Association; 1989.

10. Cherry R. Selective Auditory Attention Test (SAAT). St. Louis, MO: Auditec of St.Louis; 1980.

11. Fisher L. Fisher's Auditory Problems Checklist. Bemidji, MN: Life Products; 1976.

12. Keith RW. SCAN: A Screening Test for Auditory Processing Disorders. San Antonio, TX: Psychological Corporation; 1986.

13. Smoski WJ, Brunt MA, Tannahill JC. Listening characteristics of children with central auditory processing disorders. Lang Speech Hear Serv Sch, 1992; 23(2): 145-52.

14. VanDyke J. Evaluation of classroom listening behaviors. Rocky Mountain Journal of Communication Disorders, 1985; 1: 8-13.

15. Yathiraj A, Mascarenhas K. Effect of auditory stimulation in central auditory processing in children with CAPD. Mysore: All India Institute of Speech and Hearing, 2003.

16. Yathiraj A, Mascarenhas K. Auditory profile of children with suspected auditory processing disorder. Journal of Indian Speech and Hearing Association, 2004;18: 6-14.

17. Musiek FE, Gollegly KM, Lamb LE, Lamb P. Selected issues in screening for central auditory processing dysfunction. Semin Hear, 1990; 11(4): 372-83.

18. American Speech-Language-Hearing Association. (Central) Auditory Processing Disorders [Technical Report]. 2005. Available from www.asha.org/policy

19. American Academy of Audiology. American Academy of Audiology Clinical Practice Guidelines: Diagnosis, Treatment and Management of Children and Adults with Central Auditory Processing Disorder. American Academy of Audiology, 2010. Available from http://www.audiology.org/resources/documentlibrary/documents/capd\%20guidelines\%208-2010.pdf

20. Canadian Interorganizational Steering Group for Speech-Language Pathology and Audiology. Canadian Guidelines on Auditory Processing Disorder in Children and Adults: Assessment and Intervention; 2012.

21. Yathiraj A, Maggu AR. Screening Test for Auditory Processing (STAP): a preliminary report. J Am Acad Audiol, 2013; 24(9): 867-78.
22. Yathiraj A, Maggu AR. Screening Test for Auditory Processing (STAP): revelations from principal component analysis. SSW Reports, 2012; 34(3): 16-24.

23. Keith R. Development and standardization of SCAN-A: test of auditory processing disorders in adolescents and adults. J Am Acad Audiol, 1995; 6(4): 286-92.

24. Keith RW. SCAN-3 for Adolescents and Adults: Tests for Auditory Processing Disorders. San Antonio, TX: Pearson; 2009.

25. Schow RL, Seikel JA. Screening for (Central) Auditory Processing Disorders. In: Musiek FE, Chermak GD (eds.), Handbook of (Central) Auditory Processing Disorder: Auditory neuroscience and diagnosis. I. San Diego: Plural Publishing; 2007; 137-61.

26. Kinsella K, He W. An Aging World: 2008, International Population Reports, P95/09-1. Washington, DC: U.S. Government Printing Office, 2009.

27. Central Statistics Office, Ministry of Statistics and Programme Implementation. Situation Analysis of the Elderly in India. New Delhi: Government of India, 2011.

28. Gelfand SA, Piper N, Silman S. Consonant recognition in quiet and in noise with aging among normal hearing listeners. J Acoust Soc Am, 1986; 80(6): 1589-98.

29. Grady CL, Craik FIM. Changes in memory processing with age. Curr Opin Neurobiol, 2000; 10(2): 224-31.

30. Prosser S, Turrini M, Arslan E. Effects of different noises on speech discrimination by the elderly. Acta Otolaryngol Suppl (Stockh), 1991; 476: 136-42.

31. Tun PA, O’Kane G, Wingfield A. Distraction by competing speech in young and older adult listeners. Psychol Aging, 2002; 17(3): 453-67.

32. All India Institute of Speech and Hearing. Ethical Guidelines for Bio-behavioural Research Involving Human Subjects. Mysore: All India Institute of Speech and Hearing; 2009.

33. Tavakol M, Dennick R. Making sense of Cronbach's alpha. Int J Med Educ, 2011; 2: 53-5.

34. Moore BC, Peters RW, Glasberg BR. Detection of temporal gaps in sinusoids by elderly subjects with and without hearing loss. J Acoust Soc Am, 1992; 92: 1923-32.

35. Snell KB. Age-related changes in temporal gap detection. J Acoust Soc Am, 1997; 101: 2214-20.

36. Larrabee GJ, Levin HS. Memory self-ratings and objective test performance in a normal elderly sample. J Clin Exp Neuropsychol, 1986; 8(3): 275-84.

37. Park DC, Smith AD, Dudley WN, Lafronza VN. Effects of age and a divided attention task presented during encoding and retrieval on memory. J Exp Psychol, 1989; 15(6): 1185-91.

38. Anderson ND, Iidaka T, Cabeza R, Kapur S, McIntosh AR, Craik FI. The effects of divided attention on encoding- and retrieval-related brain activity: a PET study of younger and older adults. J Cogn Neurosci, 2000; 12(5): 775-92.

39. Katz J. Classification of auditory processing disorders. In: Katz J et al. (eds.), Central Auditory Processing: A Transdisciplinary View. St Louis: Mosby, 1992; 81-91.

40. Efron R, Crandall P, Koss B, Divenyi P, Yund E. Central auditory processing: III. The "cocktail party" effect and anterior temporal lobectomy. Brain Lang, 1983; 19(2): 254-63.

41. Ellis M. Amygdala norepinephrine involved in two separate long-term memory retrieval processes. Brain Res, 1985; 342(1): 191-5.

42. Isaacson RL, Pribram KH. The Hippocampus: Plenum Press; 1986. 
43. Stuss DT, Benson DF. Neurophysiological studies of the frontal lobes. Psychological Bulletin, 1984; 95: 3-28.

44. Hackert V, Den Heijer T, Oudkerk M, Koudstaal P, Hofman A, Breteler M. Hippocampal head size associated with verbal memory performance in nondemented elderly. Neuroimage, 2002; 17(3): 1365-72.

45. Petersen RC, Jack CR, Xu Y-C, Waring SC, O’Brien PC, Smith GE et al. Memory and MRI-based hippocampal volumes in aging and AD. Neurology, 2000; 54(3): 581-7.
46. Tisserand D, Visser P, Van Boxtel M, Jolles J. The relation between global and limbic brain volumes on MRI and cognitive performance in healthy individuals across the age range. Neurobiol Aging, 2000; 21(4): 569-76.

47. Wong P, Jin JX, Gunasekera GM, Abel R, Lee ER, Dhar S. Aging and cortical mechanisms of speech perception in noise. Neuropsychologia, 2009; 47(3): 693-703.

48. Murphy DR, Schneider BA, Speranza F, Moraglia G. A comparison of higher order auditory processes in younger and older adults. Psychol Aging, 2006; 21(4): 763-73. 